\title{
The Kelaniya-Negombo Coastal Zone and its Geological Resource Potential
}

\author{
J. W. HERATH AND A. SENANAYAKE \\ Oceanography Unit, National Aquatic Resources Agency, Crow Island, Colombo 15.
}

(Date of receipt: 29 November 1983)

(Date of acceptance: 5 March 1984)

\begin{abstract}
Recognizing the importance of the marine sciences, an Oceanography and Survey of Off-shore Area Unit has been set up within the newly established National Aquatic Resources Agency (NARA) of Sri Lanka. Work programmes initiated by NARA include the investigation of the coastal regions of the island which would be integrated with the proposed hydrographic and oceanographic surveys to be undertaken in early 1984. The present study is confined to the Kelaniya - Negombo coastal zone and is the first phase of the survey. An account is given of the general coastal features and the geological resource potential of the area. Substantial amounts of ilmenite occur at several localities along the beach. At some points bulk samples of beach sands contain over 65 per cent of the mineral ilmenite. A low grade peat deposit is described which occurs in the silted up lagoon-the Muthurajawela swamp. The importance of the rational management of the coastal zone is also discussed as coastal areas and the coastal environment are important resources for socio-economic development.
\end{abstract}

\section{Introduction}

In regard to mineral resources, the sea can be divided into five regions: marine beaches, sea water, the continental shelves, surficial sediments and the hard rock beneath the surficial sea floor sediments. A variety of minerals are extracted from the first three regions of the ocean. Some minerals mined from marine beaches include the heavy minerals resistant to chemical weathering, diamonds (southwest Africa), gold (Alaska), magnetite sands (Japan), shell sands (USA), Ilmenite-RutileZircon (Sri Lanka, Australia, India, USA, Brazil and other countries). In addition to common salt, bromine, magnesium and magnesium compounds, several other minerals are extracted from sea water. Important minerals on the continental shelves include, phosphorite, glauconite and calcareous shell deposits. Barium sulphate concretions have been dredged from about $1235 \mathrm{~m}$ off Colombo. ${ }^{3}$ The oil reserves of the continental shelves of the world have been estimated to be about equal to the resources of onshore areas of the continents. From an economic standpoint, manganese nodules are the most important on the floor of the three major oceans. Very little is known about the fifth region that of the hard rock under the ocean floor sediments. These are the better known mineral occurrences of the sea."

A great potential therefore lies in developing marine resources and the application of marine science to development can only be undertaken by people trained accordingly. Recognizing the importance of the marine sciences, Sri Lanka has 
established a new organization (1981) namèd the National Aquatic Resources, Research and Development Agency (NARA), charged with the responsibility of carrying out and co-ordinating research, development and management activities on the subject of aquatic resources (living and non-living). The establishment of NARA also satisfies a long felt need for a National Oceanography Institute for Sri Lanka.

Under the terms of the Law of the Sea Convention which was signed in Jamaica (December 1982), Sri Lanka has control of an off-shore territory approximately 20 times as large as the country's total land aren and comprises the $320 \mathrm{~km}$ Exclusive Economic Zone and Sea Bed rights beyond.

Work programmes initiated by the Oceanography Unit of NARA include the investigation of the coastal regions of the Island which would be integrated with the proposed geological and geophysical off-shore surveys to be undertaken in early 1984. The present study is confined to the Kelaniya-Negombo coastal zone and is the first phase of the survey. An account is given of the general coastal features and the geological resource potential of the area. The Muthurajawela swamp is described as it occurs in the area under investigation and the importance of the rational management of -the coastal zone is discussed.

\section{General Geography and Geology}

Sri Lanka which is a tropical island has an area of $65,000 \mathrm{sq} \cdot \mathrm{km}(25,332 \mathrm{sq}$. miles) and the island may be divided into two main physiographic divisions.

1. The low lying coastal plain with little relief and traversed by rivers which have almost reached their base level of erosion in the coastal plain.

2. The central highlands with immature drainage pattern and marked relief abounding in numerous strike, ridges, hills and mountains.

The coastal plain is narrow in the western and southern parts of the Island and the highlands towards the south rise steeply from the coastal plain. Sri Lanka lies in the monsoon region of south-east Asia and the mean rainfall for the Island is $203 \mathrm{~cm}$ ( 80 inches). The rivers have a radial distribution, the upper reaches are mainly confined to the central hill country. The radial pattern is the dominant element in the drainage pattern of Sri Lanka.

The two main rivers, draining the area under investigation include the Kelani Ganga with its mouth immediately north of Colombo and the Maha Oya with its mouth north of Negombo. Crystalline rocks of Pre-cambrian age occupy the greater part of the Island. They consist of a gneissic complex (Vijayan Series) 


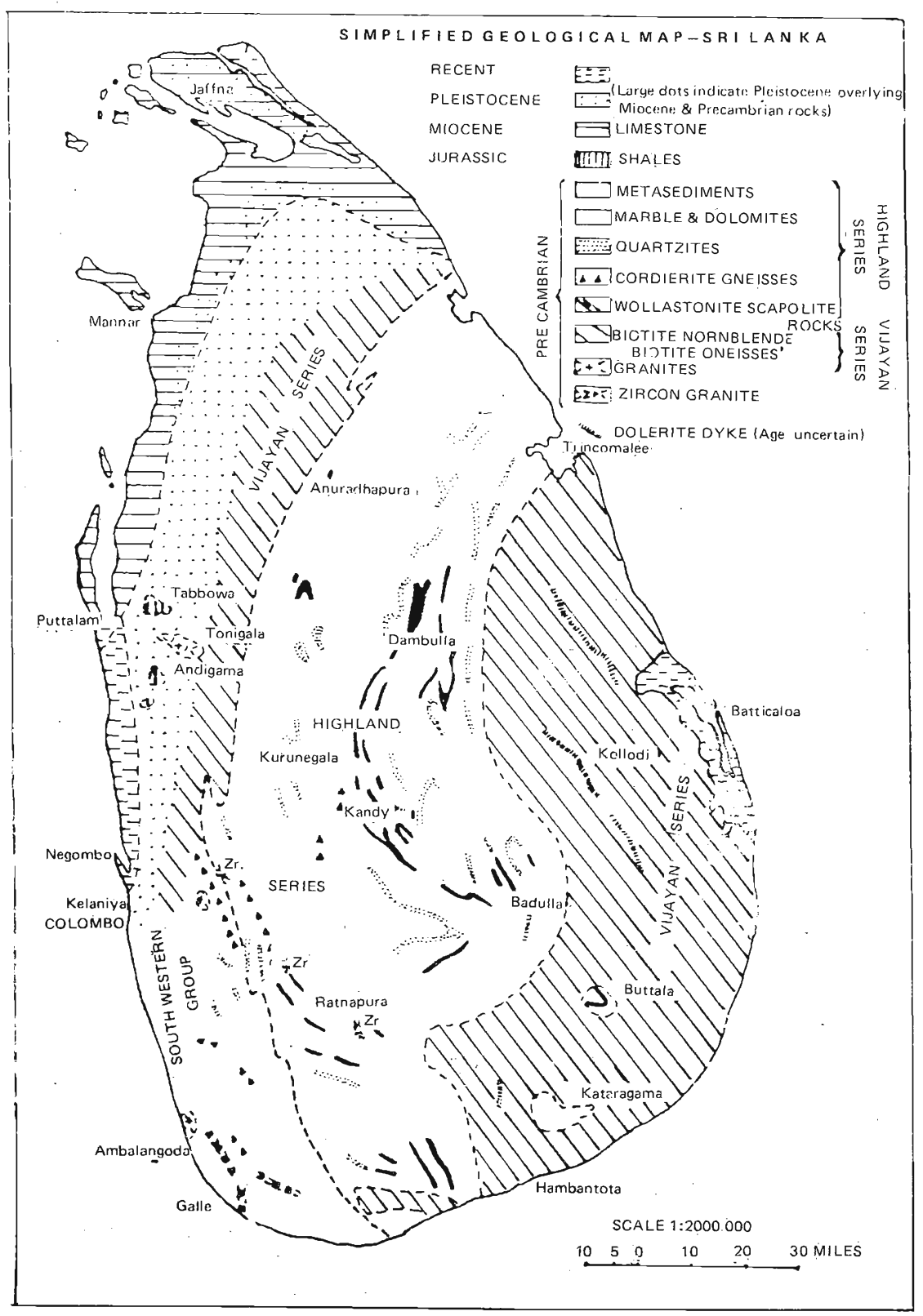

Figure 1. Geological Map of Sri Lanka. 
which attains greatest exposure in the eastern half of the Island and the central country is occupied by highly metamorphosed sediments of the Highland series which consists of quartzites, gneisses, granulites, marble, charnockitic rocks and the "Type Khondolite"' (garnet-sillimanite-graphite schist). A third group, the South Western Group is similar to the Highland Series. There are however differences between the units in terms of both lithology and metamorphic history. Rock types in this group include thin quartzites, wollastonite bearing rocks, cordierite bearing gneisses, coarse charnockitic rocks and appreciable amounts of chert. Granulites and charnockitic gneisses occur both in the gneissic complex and in the Highland Series. Rocks of the Palaeozoic consists of two Jurassic outcrops of the Tabbowa Series. Deposits of Tertiary and Post-Tertiary age are represented by the Miocene Jaffna Limestone, Pleistocene Gravels, Recent Sandstones and other formations including Lateritic Deposits (Figure 1).

The laterites overlie a variety of rock types and are largely laterites developed in situ. The warm climate and abundant rainfall alternating with dry periods, is geologically favourable to the development of laterites. The thickest laterite occupies a surface about $25 \mathrm{~m}-30 \mathrm{~m}$ above sea level between Negombo ( $40 \mathrm{~km}$ north of Colombo) and Kalutara ( $40 \mathrm{~km}$ south of Colombo). Inland it thins out and with increase of elevation passes into lateritic soils. ${ }^{1}$

The minerals, ilmenite, monazite garnet and zircon are found in abundance in the easily accessible form of beach sands at several points along the coasts of the Island. Ilmenite occurs in appreciable amounts along the beach under investigation. Beaches are an interesting area of the ocean from a mineral resource standpoint. Normally the bulk of the material forming the beach is washed down to the sea coast by rivers and streams. The material washed is derived from inland rocks by weathering processes within the drainage basin of the river or stream. Rocks of continental shelves including mineral deposits if present are usually similar to those of adjacent land. The general succession of geological formations and principal mineral deposits of Sri Lanka are presented in Table 1.

\section{Coastal Features and Bottom Sediments}

Coastal features were largely studied with the help of air photographs together with field checks where necessary. The coastal zone is classified into varying groups depending on features which could be easily identified. The photo characteristics of the various features together with some observations made in the field in regard to their economic value are discussed. A series of bottom sediments taken at various points up to about $1.5 \mathrm{~km}$ off-shore have been examined by a number of organisations and the results obtained are also discussed. 
Table 1. General succession of geological formations and principal mineral deposits in Sri Lanka.

\begin{tabular}{|c|c|c|c|}
\hline \multicolumn{2}{|c|}{$\begin{array}{c}\text { Principal Geological } \\
\text { Divisions }\end{array}$} & \multirow[t]{2}{*}{ Principal Formations } & \multirow[t]{2}{*}{$\begin{array}{l}\text { Important Mineral } \\
\text { Deposits }\end{array}$} \\
\hline Era & Period & & \\
\hline ANTHROPOZOIC & $\begin{array}{l}\text { HOLOCENE } \\
\text { (RECENT) }\end{array}$ & $\begin{array}{l}\text { Recent residual and } \\
\text { alluvial deposits, } \\
\text { blown sand, coastal } \\
\text { sandstone, coral and } \\
\text { Shell formations, } \\
\text { beach mineral sands; } \\
\text { gem gravels, lagoonal \& } \\
\text { estuarine deposits, peat }\end{array}$ & $\begin{array}{l}\text { Kaolin, Ball Clay, } \\
\text { Refractory Bond Clay } \\
\text { Alluvial Clay, Silica } \\
\text { sand, ilmenite, rutile, } \\
\text { monazite, zircon, } \\
\text { Baddyleite, garnet, } \\
\text { gems, thorianite, coral, } \\
\text { shell, clay ochres }\end{array}$ \\
\hline CENOZOIC & $\begin{array}{l}\text { (QUATERNARY) } \\
\text { PLEISTOCENE }\end{array}$ & $\begin{array}{l}\text { Laterites (may extend } \\
\text { from recent to Tertiary } \\
\text { Periods) Gravels, } \\
\text { Red earths }\end{array}$ & $\begin{array}{l}\text { Lateries, Limonitic } \\
\text { iron ore, red sands, } \\
\text { Gems }\end{array}$ \\
\hline . & $\begin{array}{l}\text { (TERTIARY) } \\
\text { MIOCENE }\end{array}$ & Limestone & Limestone \\
\hline MESOZOIC & JURASSIC & $\begin{array}{l}\text { Shales, Carbonaceous } \\
\text { Shales and arkosic } \\
\text { sandstones }\end{array}$ & Shales \\
\hline PALAEOZOIC & - & Absent & - \\
\hline ARCHAEOZOIC & PRE-CAMBRIAN & $\begin{array}{l}\text { Highland Series } \\
\text { metamorphosed } \\
\text { Sediments } \\
\text { Vijayan Series } \\
\text { Gneissic complex } \\
\text { Intrusives Granites, } \\
\text { dykes and dolorites. } \\
\text { Southwestern Group }\end{array}$ & $\begin{array}{l}\text { Serpentinite, marble, } \\
\text { Dolomite, Magnesite, } \\
\text { Quartz, Allanite, } \\
\text { Felspar, Graphite, } \\
\text { Mica, Cordietrie, } \\
\text { Apatite, Clrert, } \\
\text { Wollastonite, } \\
\text { Sillimanite, magnetite, } \\
\text { copper. }\end{array}$ \\
\hline
\end{tabular}

AFTER HERATH 1980 (2)

The entire sea beach is covered by recent beach sand deposits and is devoid of any vegetation. Ilmenite occurs in appreciable amounts and in such a manner that allows profitable extraction at certain points along the beach mainly near the Kelani river mouth and immediately north of this point. The wind blown sands immediately adjoining the beach are not so well developed. The mineral contents (ilmenite - rutile-zircon) in these blown sands are fairly low compared to the sands in the beach. Vegetation when present is mostly of a scattered type and the sands are of no economic value. Lagoonal flats are well developed in the Negombo Lagoonal area. Vegetation when present is mainly of the mangrove type. The clays contain varying amounts of organic matter. The lagoons are important from the point of view of marine living resources. The flood plain deposits are 


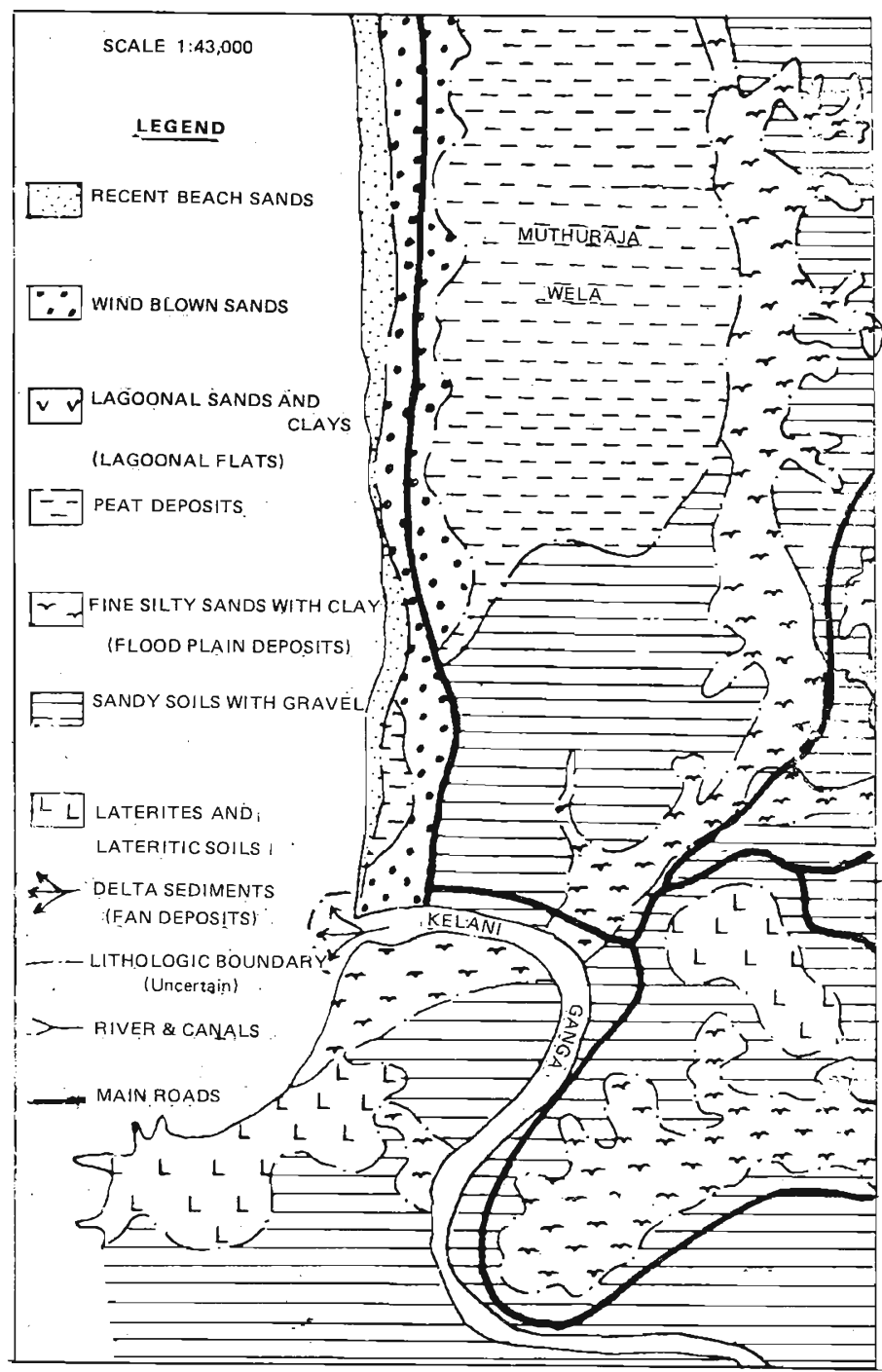

Figure 2. Coastal Features of the Country North of the Kelani River Mouth. 
mainly under paddy cultivation and these deposits consist of fine silty sands with clays. The Muthurajawela swamp covers an area of $35 \mathrm{sq} \mathrm{km}$. Marshy vegetation is common in the swamp which is a silted up lagoon, presently a peat deposit. Laterites are well developed in the area examined and they are confined to slightly elevated land with mixed vegetation. The laterites are mainly used as a building material and they are also ideal formations for storage of underground water. Sandy soils with gravel cover areas mainly under coconut cultivation. Fan type deposits of delta sediments are at the mouths of the two major rivers (Kelani and Maha Oya).

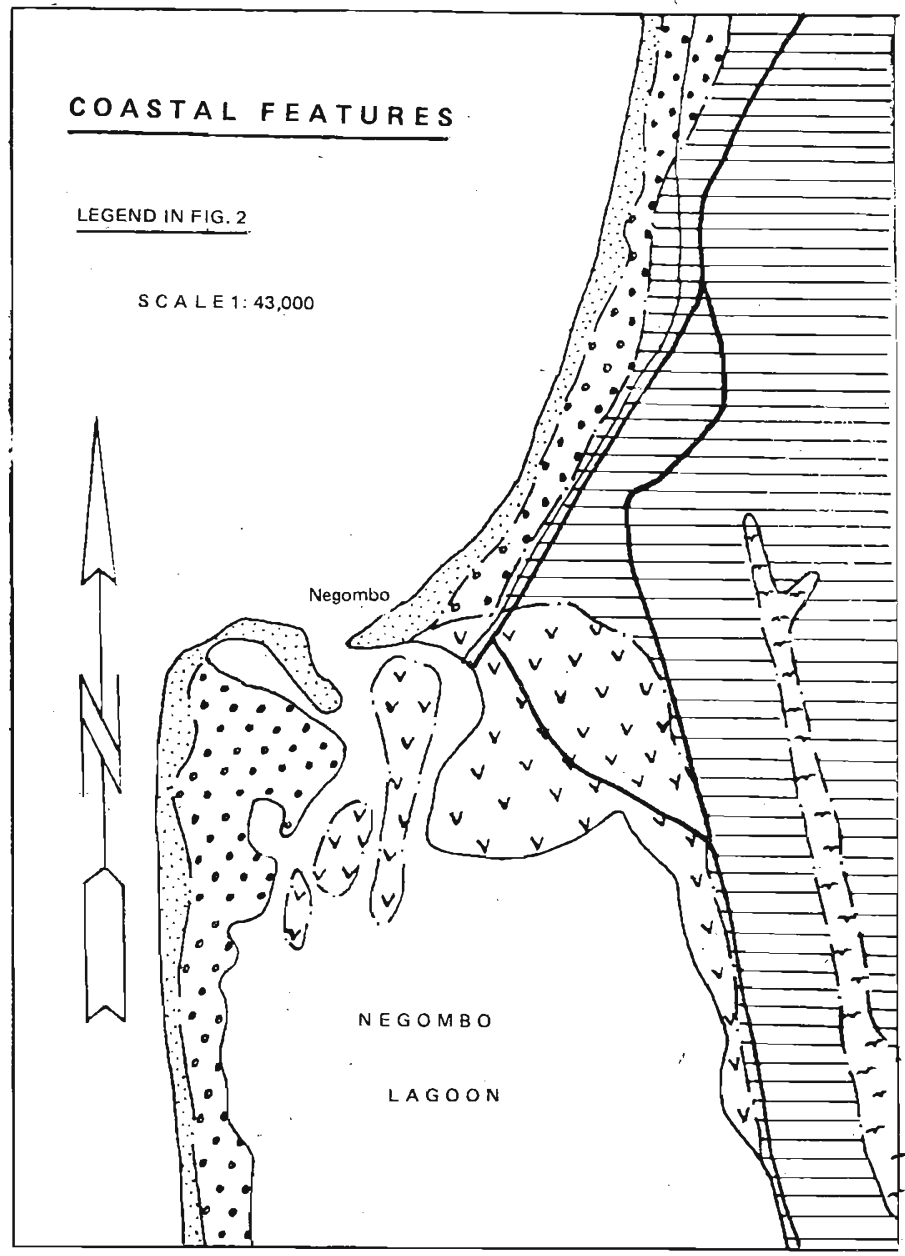

Figure 3. Coastal Features of the Negombo Area. 
They are fine to coarse sand deposits and the bulk of the ilmenite has been washed down to the sea by the Kelani river. Many parts of the coastal plain owe their flatness not to erosion of the country rocks but to the presence of extensive flat lying sedimentary deposits of more recent age lying on a already peneplained basement of crystalline rocks.

Bottom sediments have been collected from off-shore areas during reconnaissance surveys. Samples examined from a depth of about $8-10 \mathrm{~m}$ off the Hendala and Lansiyawatta coast revealed that the bottom sediments in this area were mostly black sands. Other off-shore sediments immediately north of Lansiyawatta are mainly composed of brown and yellow sands together with occasional green mud which has been identified as glauconite. The main rock type in the area surveyed is a hornblende biotite gneiss. The glauconite may be the result of the alteration of detrital biotite. Glauconite deposits are usually confined to shallow water sediments. Surveys carried out by the Institute of Marine Research, Bergen, reveal the presence of a fairly wide shelf up to about $25 \mathrm{~km}$ (between Kelaniya and Negombo) with an even flat bottom. The depth of the water column at around $25 \mathrm{~km}$ from the shore is about $50 \mathrm{~m}$, thereafter there is a sudden drop of the wide shelf. The near shore part of the shelf is characterised with areas of even flat bottom and the outer parts are rough and uneven with the presence of coral formations at certain points.

Figure 2 is presented to show the coastal features of the country north of the Kelani river mouth. The features shown are easily identified in air photographs. The area north of this region has a very similar pattern as far as coastal features are concerned, and it includes the Negombo lagoon with its Lagoonal Sands and Clays (Figure 3).

\section{The Muthurajawela Peat Deposits}

The largest known deposit of peat in the Island is in the Muthurajawela swamp situated north of Colombo (see Figure 2). The peat deposit covers an area of about 35 square $\mathrm{km}$ with an average thickness of $4 \mathrm{~m}$ of peat. The maximum observed thickness has been $6 \mathrm{~m}$. As a result of detailed investigations by the Geological Survey Department 50 million tons (wet basis) of peat have been proved. Over 90 per cent of this is water which leaves only 5 million tons of dry peat. The formations are by no means uniform in character. Drying is one of the great problems of peat working. The draining facilities in the swamp are poor and the normal water level in the greater part of the swamp is about $30 \mathrm{~cm}$ above the surface. The water content in the peat could however be reduced to as low as 10 to 15 per cent by sun drying over a period of 10 - 12 days. Improved solar drying methods could now be used successfully for purposes of drying peat. 
Detailed laboratory investigations have been carried out in the Geological Survey laboratories on a large number of peat samples collected during field investigations. The moisture content, ash, volatile matter, nitrogen, total sulphur, incombustible sulphur and fixed carbon have been determined in order to assess its value for industrial purposes. Table 2 is presented to show the results obtained. The ash content of the peat is fairly high and the percentage carbon is low, around 30 per cent, when compared with true peat material with a carbon content between 50 and 60 per cent. These results indicate that the peat is of low quality and does not approach true peat in composition.

Table 2. Chemical analyses of Muthurajawela peat

\begin{tabular}{|c|c|c|c|c|c|c|}
\hline Sample No. & & $1-\mathrm{A}$ & $3-\mathbf{A}$ & $8-C$ & $10-C$ & $13-\mathbf{A}$ \\
\hline Moisture $\%$ & & 7834 & 82.22 & 83.52 & 79.39 & 70.69 \\
\hline Ash $\%$ & & 16.95 & 24.92 & 11.24 & 30.46 & 27.65 \\
\hline Volatile Matter $\%$ & & 56.07 & 44.01 & 51.22 & 42.69 & 46.25 \\
\hline Nitrogen $\%$ & & 0.855 & 04.30 & 0.918 & 0.701 & 0.726 \\
\hline Total Sulphur $\%$ & & 4.15 & 5.08 & 5.14 & 4.78 & 3.56 \\
\hline Fixed Carbon $\%$ & & 26.98 & 31.07 & 37.54 & 26.75 & 26.00 \\
\hline Ash Content & 一 & \multirow{4}{*}{\multicolumn{5}{|c|}{$\begin{array}{l}\text { range } 10 \text { to } 30 \text { per cent (Average } 20 \text { ) } \\
\text { range } 1 \text { to } 8 \text { per cent (Average } 5 \text { ) } \\
\text { range } 80 \text { to } 90 \text { per cent } \\
\text { less than } 1 \text { per cent }\end{array}$}} \\
\hline Sulphur Content & 一 & & & & & \\
\hline Moisture & 一 & & & & & \\
\hline Nitrogen Content & - & & & & & \\
\hline
\end{tabular}

Geological Survey Department,

Colombo 2.

True peat has a calorific value between 7200 and 10800 B.t.us., it is chiefly used in the form of briquettes or compressed material for industrial heating (producer gas). The USSR is believed to be the largest producer of peat in the world and it is consumed for fuel and agricultural purposes. True peat on distillation yields coke, tar, ammonia, fuel gas, and other products. Much of the technological developments on peat throughout the world are related to methods and processes of utilising it as a fuel.

The Muthurajawela peat deposits examined so far are considered to be of low grade quality. Further field investigations to locate good quality deposits, together with research and development, making use of present day advanced technologies for processing peat may have to be undertaken to assess its suitability for use as a fuel. Before a final decision is taken for re-examination of the peat deposits it is desirable to study all previous reports on the peat deposits which undoubtedly point out to the unsuitability of the material for use as a fuel. The development which has already taken place around the peat deposit may also have to be given due con- 
sideration in the event a decision is taken to mine the deposit. The stability of the developed area (areas of the peat deposits reclaimed by filling) may be affected over the years if the deposit is mined.

\section{Geological Resource Potential}

The sampling undertaken was from an area between the mouth of the Kelani river (near Crow Island) to about the area immediately north of the mouth of the Maha Oya. Forty nine auger holes were put down and 260 samples were collected. Twelve (12) samples of beachrock (sandstone) were also collected during the survey. The area about 2 kilometers north from the mouth of the Kelani river was examined in detail to gather information on lenses and pockets of ilmenite concentrations which may occur below the surface sands (see Figure 4). Some samples of sands appeared to be almost black in colour and these sands invariably contain very high percentages of ilmenite. The highest concentration of ilmenite occurs; on the beach near the mouth of the Kelani river. Analyses of the samples were carried out in the laboratories of the Geological Survey Department. Fifty samples of beach sands were closely examined, 28 samples were analysed to detcrmine the mineral content and 3 samples of beach rock were examined in detail. The sampling area is shown in Figure 1. (Colombo to Negombo).

A current bedded beach rock of recent age forms a conspicuous feature of the coast north of Colombo (Figure 4). It is a coarse to medium grained rock and consists of ilmenite, quartz grains and shell fragments held together by a calcareous cement or ferruginous material.

The ilmenite is arranged in bands, the beach rock then has a banded appearance (Figure 5). The ilmenite content of the rock varies from place to place. At certain points the ilmenite content may so increase that the rock becomes an ilmenite rock with a specific gravity as high as 3.8 .

Other minerals present in the sandstone include monazite, zircon, garnet, magnetite and rutile. These minerals which occur in varying amounts are usually present in quantities less than 5 per cent and the monazite content seldom rises above 3 per cent. Similar current bedded beach rocks are exposed on the east coast and are well developed between Batticaloa and Arugam Bay.

Table 3 is presented to show the results of analyses of some samples of beach sands. Most of the minerals present are the heavy minerals resistant to chemical weathering. There is no pattern whatsoever as far as the percentages of minerals are concerned in the mineral assemblages in the beach sands. The character of the deposits vary considerably and the mineral contents vary both with depth and ' within a few metres along the beach. Figure 4 is presented to show a generalized cross- 


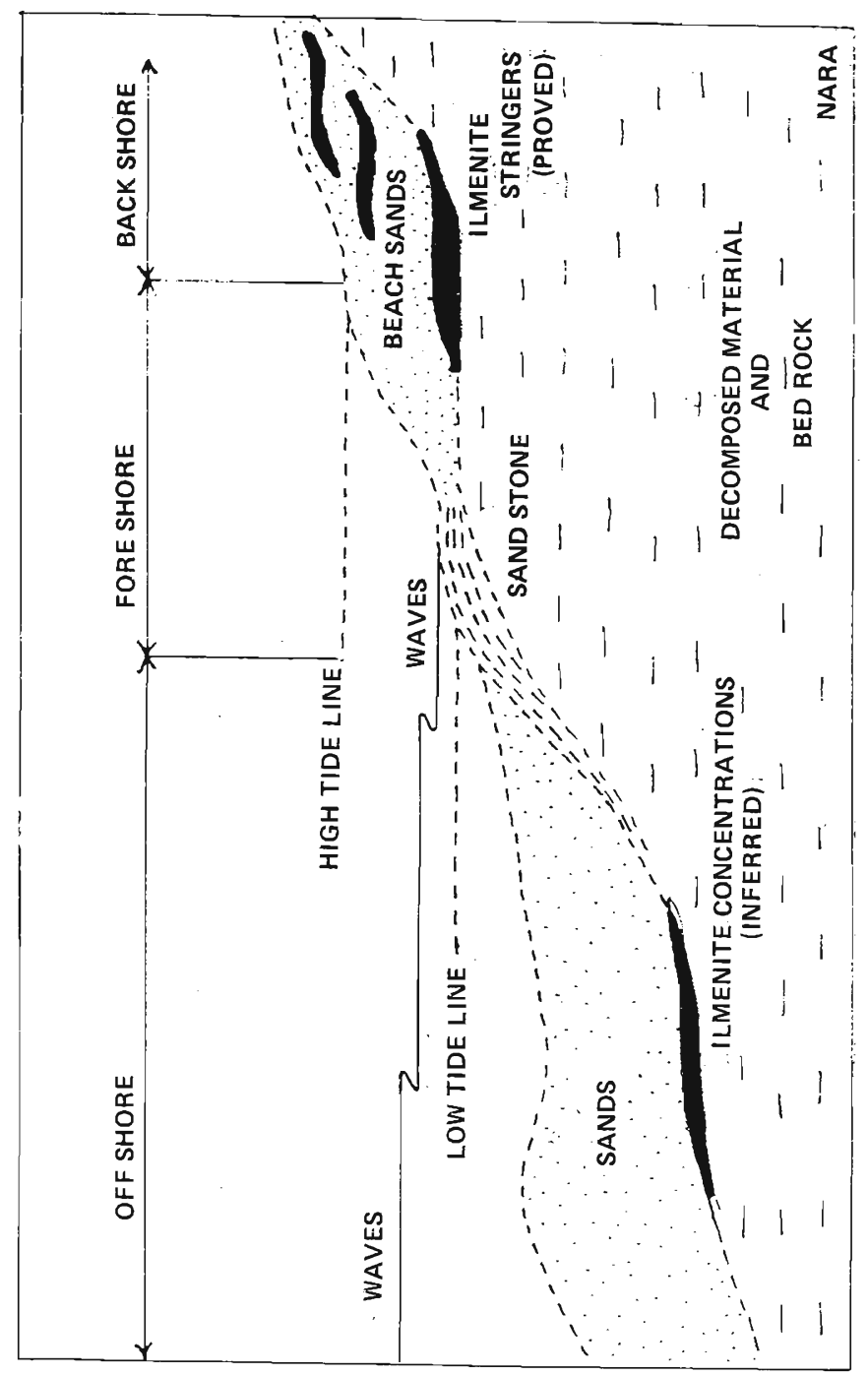




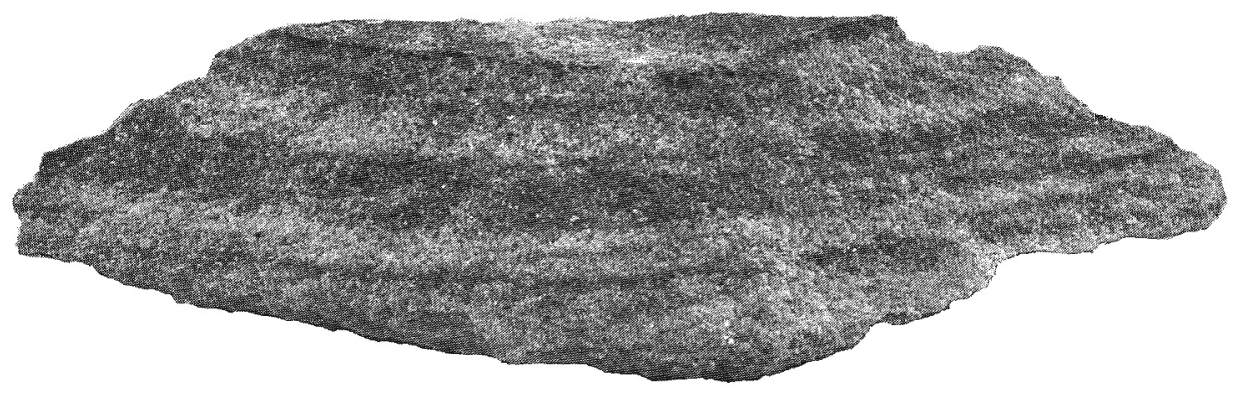

Figure 5. Beach Rock showing Bands of Jlmenite.

sectional view of the beach about 2 kilometers north of the mouth of the Kelani river. There are a series of ilmenite stringers at depth. The jigging action of the waves may have been responsible for concentrating the heavy minerals in certain zones of the beach.

Ilmenite is the main heavy mineral present within the area studied. At some points over 75 per cent ilmenite is present in the beach sands. These concentrations are close to the mouth of the Kelani river (Figure 6). All other minerals occur in negligible amounts and are of no economic value at the moment. At some points along a distance of about $3 \mathrm{~km}$ (immediately north of the mouth of the Kelani river) over 25,000 tons of ilmenite could be recovered annually.

According to Wadia and Fernando" "the beach for several miles north of the Kelani river is formed of sand rich in ilmenite. Wave action produces a clean concentrate at certain seasons. The concentrate forms most rapidly in the period between the two monsoons. The Kelani black sands contain 2 to 3 per cent of. monazite, as much as 14 per cent has been reported on one occasion from the coast near Pamunugama and in the sand bars at the mouth of the Maha Oya, 7 per cent of monazite has been recorded."

The present investigation reveals that ilmenite is the only minzral of economic value which could be recovered from the area investigated. 


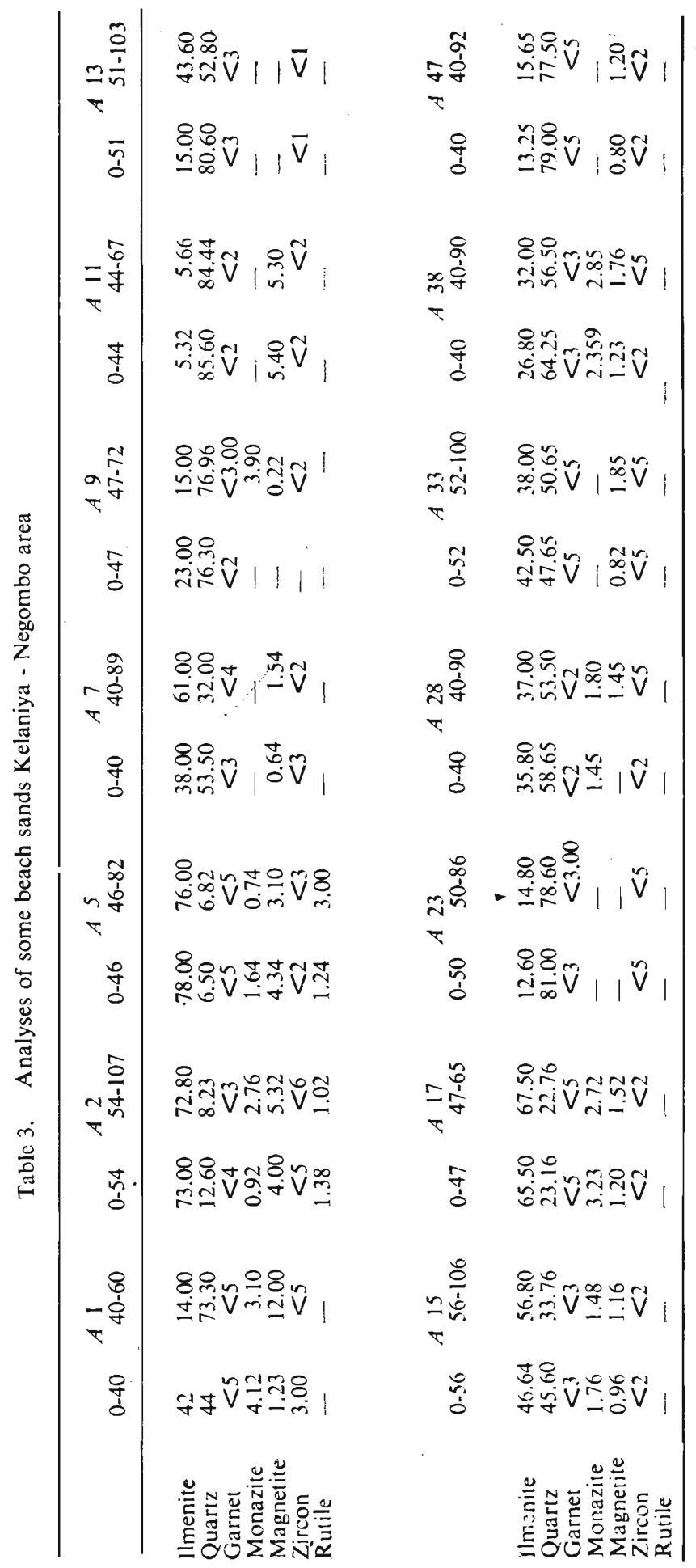




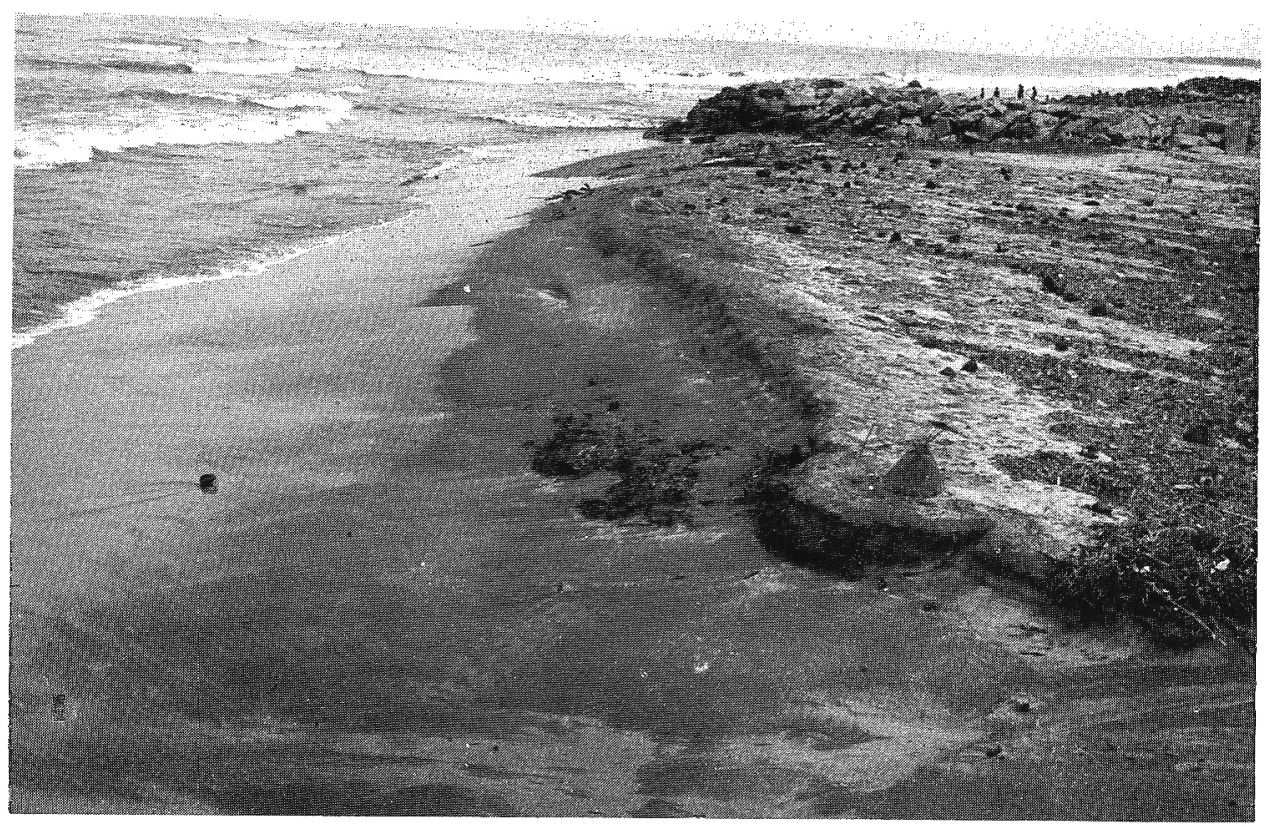

Figure 6. Black Sands (Ilmenite) near Mouth of Kelani River.

\section{Importance of the Rational Management of the Coastal Zone}

The importance of the marine environment is clearly indicated by the fact that the seas cover 71 per cent of the world's surface. Some two-thirds of the world's population are now considered to live near the coast. The coastal areas and environment are therefore considered to be a resource and wherever possible the coastal zone should be developed according to an overall plan. This has important implications for developing countries in which coastal settlements are still in the process of evolving.

There are distinct advantages in living where land and sea meet and interact in the coastal area. The modern rise of coastal communities in developing countries is linked to the commercial use of the oceans. The sea coast has been recognized as a venue for relaxation and recreation. Many countries today have a highly developed tourist industry. Coastal areas and therefore the sea in general receive ultimately by far the greatest part of man's waste materials. The resulting marine pollution has focussed the attention of nations on this problem.

In the management of the coastal zone, problems cannot be solved by allocating different parts of the coast for different functions. A port loading facility if established without considering coastal winds and currents can result in destruc- 
tion of surrounding marine life. Similarly, by ignoring prevailing oceanographic conditions improper siting of a submarine sewage out-fall can result in destruction to marine life and in contamination of beaches. If the sea is allowed to encroach on the land, damage can result sometimes on a considerable scale (see Figure 7). Indiscriminate mining of coral reefs (as in Sri Lanka) barriers which have taken thousands of years to build up may cause severe coastal erosion. Mining activities along coastal areas if not done systematically may also result in coastal erosion. The Vallaichenai lagoon on the east coast is today completely devoid of marine life as a result of effluent from the paper factory being drained into the lagoon. Any development affecting the marine environment and the sea coast, is therefore potentially harmful if considered in isolation and without a proper plan. Integrated surveys are therefore of great value in the management of coastal areas and scientists from various disciplines may have to be consulted when work programmes in the coastal environment are undertaken.

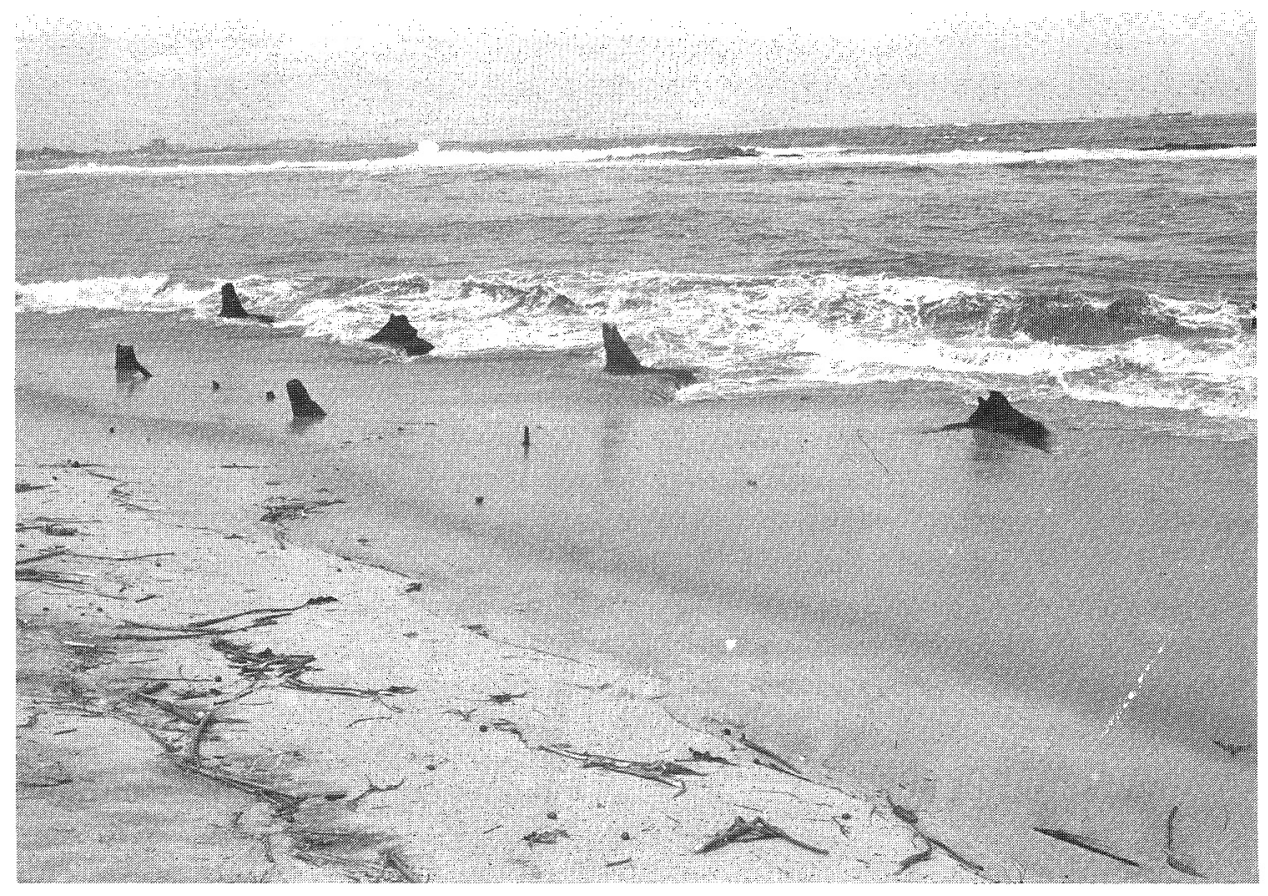

Figure 7. Sea Erosion near Pegasus Reef Hotel. 


\section{Summary and Conclusions}

The potential of the seas is extraordinary and is destined to shape the future of mankind in a very particular way. The coastal areas and the coastal environment are important resources for socio-economic development. With respect to mineral resources the same type of minerals can be expected to be found in beach deposits that are found in placer deposits onshore. A study of the geology and mineralogy of the rocks in the drainage areas of rivers providing sediments for a particular beach will normally indicate whether valuable minerals can be expected to be found in the beach.

It is generally safe to assume that similar deposits of minerals exist in the off-shore areas as in those beaches onshore. The technology of exploring off-shore deposits is already developed in the systems used to sample off-shore sediments for oil. At present Sri Lanka is devoid of capabilities to assess the mineral resources of off-shore areas - the continental shelves and surficial sediments. It is proposed however, to commence as early as possible hydrographic and oceanographic surveys with assistance from a number of foreign organizations. The present surveys of coastal areas would eventually be integrated with the proposed geological and geophysical surveys of off-shore areas. These surveys are to be undertaken by the National Aquatic Resources Agency.

The current investigation has shown that the beach deposits vary widely in character. The mineral ilmenite occurs in appreciable amounts and is the only mineral present which is of economic importance, provided markets are available for the sale of this material. Samples containing over 75 per cent ilmenite have been observed near the mouth of the Kelani river and over 25,000 tons of ilmenite can be recovered from this area each year. The other deposits of interest are the Muthurajawela peat deposits. At present they do not seem to be of any value. Further surveys have to be undertaken to locate areas with good quality peat deposits, after all available reports have been studied. The swamp however, could be developed for purposes of aquaculture. Mention may also be made that extensive alluvial deposits occur along the Kelani river course east of Colombo. Next to these deposits those along the course of the Maha Oya are the most exploited claỹ deposits of Sri Lanka for the brick and tile industry.

The rational management of the coastal environment includes respect for an enhancement of, the quality of life in the broadest sense. Among the most important activities in the coastal areas, we may mention fishing, aquaculture, prospecting for hydrocarbons, production of mineral raw materials, town planning, recreation, industry, sports and other activities. This variety of activities makes it necessary that they should be co-ordinated and harmonised in a suitable framework so as to avoid discordances between them and the hinterland activities. Surveys of an 
integrated nature are therefore of value in the management of coastal areas and scientists from various disciplines may have to be consulted when necessary, where coastal development is concerned.

\section{Acknowledgements}

The authors wish to thank Mr. H. D. N. C. Pathirana (Geologist). Geological Survey Department for help in the interpretation of air-photographs covering the area and they wish to express their gratitude to the Director of the Geological Survey Department (Mr. L. K. Seneviratne) for assisting in the analyses of samples. Mr. S. R. Amaratunge. Research Assistant, NARA assisted in carrying out the field surveys and the Photography Division of NARA took the necessary photo illustrations. This paper is published with the kind permission of the Chairman (Dr. Hiran W. Jayewardene), National Aquatic Resources Agency.

\section{References}

1. HERATH, J. W. \& PATTIARATCHI, D. B. (1963)。 Geology, Composition and Mineralogy of Ceylon Laterites, Cey: Geog. 17, 11-20.

2. HERATH, J. W. (1980). Mineral Resources of Sri Lanka Eco. Bull. No. 2, Geological Survey Department 14-18.

3. JONES, E. J. (1887). On some nodular stones obtained by trawling off Colombo in 675 fathoms of water, J. Asiatic, Soc. Bengal, 56: 209 (in Mero 1976).

4. MERO, J. L. (1973). The Mineral Resources of the Sea, Elsevier, Holland, 1-20.

5. WADIA, D. N. \& FERNANDO, L. J. D. (1945). Ilmenite, Monazite and Zircon, Prof. Paper No. 2, Geological Survev Department 1+22. 